with equity: Social change and challenges to education in Chile". En: Mazurek, K.; Winzer, M. y Majorek, C. (Eds.); Education in a global society: A comparative perspective. Allyn \& Bacon, Boston, 2000. / Bruer, John T.; Schools for thought: A science of learning in the classroom. MIT Press, Cambridge, Massachusetts, 1993. / Coll, César; "Algunos desafíos de la educación básica en el umbral del nuevo milenio". Perfiles Educativos, 83/84, 1999. pp. 8-26. / Delors, Jacques; La educación encierra un tesoro. Ediciones UNESCO, París, 1996. / Filp, Johanna; Cardemil, Cecilia; Donoso, Sebastián; Torres, Jaime; "La escuela icómplice del fracaso escolar?". Revista de Tecnología Educativa (OEA), No4, Vol. 7, 1981, pp. 340-358. / Ghilardi, Francesco; Crisis y perspectivas de la profesión docente. Gedisa, Barcelona, 1993. / Institut d'Educació de Barcelona Projecte Educatiu de Ciutat; Barcelona educació. Monogràfic No 2, Barcelona, 1998.

/ Letwin, Olivier; "Objetivos de la enseñanza escolar: La importancia de la base". Estudios Públicos, 78, 2000, pp. 165-172. / Marchesi, Alvaro, Martín, Elena; Calidad de la enseñanza en tiempos de cambio. Alianza Editorial, Madrid, 1998. National Commission on Excellence in Education; $A$ nation at risk: The imperative for educational reform. A report to the nation and the Secretary of Education, United States Department of Education, Washington, 1983. / Ravitch, Diane; Left back: A century of failed school reforms. Simon \& Schuster, Nueva York, 2000. / Stanton, Jessie; "The ideal teacher and how she grows". Young Children, Mayo, 1990, p.19. / Yarnit, Martin; Towns, cities and regions in the learning age: $A$ survey of learning communities. A report submitted to the CERI/ OCDE, 2000.

\section{Exteriores de los edificios educacionales Tomás Browne}

Un arquitecto, casi instintivamente para tener palabra -escrita u oral-acerca de la arquitectura, se ubica en un "lugar" y trae a presencia los edificios que sitúan lo que se pretende afirmar. Situarse y sitiar desde un lugar, coloca al arquitecto a una distancia en la cual es posible contemplar el espacio del que se quiere hablar, y hacer de éste un asunto arquitectónico.

En virtud de lo dicho, y para hablar de los edificios destinados a la educación, comienzo haciendo el catálogo de los edificios que he tenido presentes como telón de fondo de esta reflexión. No me referiré a los colegios que fundaron las colonias de extranjeros residentes en el país, porque en sus comienzos ellos se constituyeron autónomamente respecto del desarrollo de la educación en Chile.

Los liceos: Instituto Nacional, Barros Arana, Manuel de Salas, Liceo $\mathrm{N}^{o} 1$ de Niñas de Viña del Mar y el Liceo $\mathrm{N}^{\circ} 7$ de Providencia; los colegios de los SS.CC. de la Alameda y posteriormente de Manquehue, San Ignacio de Alonso Ovalle y Pocuro, y el de los Padres Alemanes en Bellavista, posteriormente Verbo Divino en Presidente Errázuriz; también el colegio Saint George de la Pirámide, casi todos en la ciudad de Santiago.

Este texto no es acerca de la historia de las escuelas como institución, iniciadas como "escuelas palatinas" por Carlomagno en el siglo VIII. Tampoco trata del desarrollo de éstas en nuestro país a partir del siglo XIX (fecha en la que comienzan a construirse edificios cuyo destino exclusivo era el impartir educación) a los tiempos actuales. En todo caso, antes de mediados del siglo XIX en Chile, la educación se impartía en edificios ideados para otros usos. El punto de vista del texto es aquel del habitante de la ciudad, que camina por el exterior de estas escuelas y colegios, para luego adentrarse en ellos. Ocurre por tanto que quien recorre estos edificios primeramente por su exterior y es detenido para entrar en ellos, se detiene ante una concreta fachada.

La fachada es en arquitectura aquello que se presenta con mayor integridad. La fachada permite de-morar el recorrido por la ciudad, a diferencia del interior que es el morar de

\section{School building exteriors \\ Tomás Browne}

When an architect needs words, either written or spoken, for architecture, almost instinctively he "locates" himself by bringing to mind the buildings that place what he wants to say. Situating and surrounding himself in a place gives him the distance from which to contemplate the space he wants to talk about, transforming it into a matter of architecture.

So in order to talk about buildings for education I shall start with a list of the buildings that provided the backdrop for this reflection. I shall not refer to the schools set up by the expatriate communities, because initially they were formed outside the national educational tradition.

The state schools (liceos): Instituto Nacional, Barros Arana, Manuel de Salas, Liceo $\mathrm{N}^{\circ} 1$ for Girls in Viña del Mar, and Liceo $\mathrm{N}^{\circ} 7$ in Providencia. The religious foundations (colegios): the Sacred Hearts in Alameda, later in Manquehue, San Ignacio de Alonso Ovalle and Pocuro, and the Padres Alemanes in Bellavista, later to become the Verbo Divino in Presidente Errázuriz; and Saint George in La Pirámide, almost all of them in Santiago.

This article will not discuss the history of schools as institutions (dating back to the Palatine Schools founded by Charlemagne in the $8^{\text {th }}$ century), nor the development of schools in Chile up to the present day, beginning in the early $19^{\text {th }}$ century, when the first buildings designed exclusively as schools began to go up. Before that date, education took place in buildings meant for other uses. Rather, this is the viewpoint of an inhabitant of the city, as he walks past the outside of these schools and then is drawn inside. In this process, the subject's attention is arrested by the outside, the facade.

The facade, architecturally speaking, is the building's most integral expression. It is the facade that slows us in our tour of the city, whereas the interior holds the city within it. The slowdown, the delay at the facade, the experience of being held by it in its integrity, by the conception of the building, raises at first hand the question of what it means in a historic context, and its relationship with the decision to construct city and country. 
la ciudad. La de-mora en la fachada permite preguntarse de primera fuente, como experiencia de quien es detenido ante ella como algo íntegro, por el modo de concebir el edificio, qué ha significado en su decurso en el tiempo y su relación con una voluntad de constituir la ciudad y el país.

\section{Momento primero. 1900 - 1960: \\ El palacio y la iglesia}

A grandes rasgos, podemos distinguir dos modalidades de fachadas en los edificios educacionales.

La primera es la del liceo. Desde su fachada exterior, con la mirada detenida en ella, se presenta como un edificio de carácter cívico y republicano; un "palacio", representación del estado educador y continuador de la tradición del "palacio" de Carlomagno que acogió las primeras escuelas. Su interior se ordena a grosso modo en torno al patio; patio de actos propios de una civilidad. La idea de liceo como establecimiento está asociada también como institución a la figura de un educador, la del "maestro" de escuela, proveniente de la escuela normalista.

Algunos de estos liceos desarrollaron también internados, modalidad que permitía acoger a los estudiantes venidos de provincia a la capital (o del campo a la ciudad en provincias). Otros liceos tuvieron una connotación de escuelas de Artes y Oficios, lo que implicaba incluir, junto a dormitorios, aulas y patio cívico, los talleres donde se impartía una enseñanza relacionada con el mundo laboral.

Otra modalidad de fachada es la de los colegios de congregación. Estos colegios se insertan y presentan a la ciudad a través de la fachada de la iglesia, forma que preside y gobierna toda su relación con el exterior y el barrio. El interior, consecuente con la tradición eclesiástica, está regido por la estructura de un claustro. Así también, la figura del educador es la del "director espiritual", a diferencia del "maestro" de liceo. Si el liceo acogió además de las aulas, el internado, los talleres etc., que fueron característicos en cuanto al rol social de la edificación, los colegios de congregación desarrollaron a su interior otros modos de relacionarse con la ciudad y el mundo de la cultura, o más bien a la inversa, generaron un modo de llevar la ciudad y la cultura al interior de ellos. Así, incluyeron teatro, biblioteca y un museo, por lo general de ciencias naturales.

A partir de las consideraciones anteriores, puede afirmarse que el liceo era un edificio que se proyectaba de cara a la ciudad, de frente al país como un signo del Estado; contrariamente, los colegios de congregación se proyectaban hacia adentro, llevando la ciudad y el país a su interior.

En ambos casos, tanto liceo (asociado al Estado) como colegio (asociado a una congregación), son edificios ubicados generalmente en medio de una ciudad ya constituida, distinguiéndose de los otros no sólo por su especificidad y tamaño sino por su potencia como signo (palacio o iglesia), representada en la fachada urbana.

\section{Momento segundo. 1960-1980:}

\section{Topología y campus}

La situación anterior de liceos y colegios es válida aproximadamente hasta la década del '60. En el caso de Santiago, el crecimiento de la ciudad hace que los establecimientos que hemos nombrado al comienzo tomen la opción de acercarse a los barrios de las familias que han dejado al centro y que tradicionalmente se han educado en sus colegios. Esto provocará un cambio en la connotación y rol del edificio escolar respecto a la ciudad. En el caso de los liceos $\mathrm{N}^{\circ} 7$ de Providencia y $\mathrm{N}^{\circ} 1$ de Niñas de Viña del Mar, dejan de apoyarse en la imagen
First moment. From 1900 to 1960 :

Palace and church

In general terms we can speak of two forms of facades in educational buildings. One belongs to the state or lay school, and a close look shows how it presents itself as a civic building, in the spirit of the republic, post Independence. It is a "palace", a representation of the state as educator, and a continuation of the tradition of Charlemagne's palaces that housed the first schools. Internally it is organized, roughly, around a courtyard, an appropriate place for the ceremonies of civil society. The idea of the school as an institution is also associated with a particular image of the teacher, that of the schoolmaster, which comes from the old teacher training schools.

Some of these schools also catered for boarders, which allowed them to receive students from the provinces in the capital, or those from the countryside in the provincial towns. Others were more like technical schools, which meant that along with dormitories, classrooms and courtyard they also included workshops for work-related teaching.

The religious schools, by contrast, make their presence felt in the city with a church-like facade that sets the tone for their relationship with the outside world and the neighborhood. The ecclesiastical tradition carries through in the interior, which is structured like a cloister, and the figure of the teacher is more like that of a "spiritual director" than the schoolmaster of the state school.

While the state schools added residential buildings and workshops to the classrooms -in an expression of the social role of the buildingthe religious schools developed other ways of relating to the city and the world of culture. They brought these into their own interior with theatres, libraries and museums, usually for natural sciences.

We can thus say that the state school building faced outwards, to the city and to the country, as a symbol of the state, while the religious schools faced inwards, drawing city and country into themselves. In both cases the schools were usually located in an existing city, and stood out from other buildings not only by their size and their specific purpose but also for the symbolic association with state or church they represented in the city facade.
Second moment. From 1960 to 1980 :

Topology and campus

The situation described above holds true until around the middle of the 1960s. Then, in Santiago the growth of the city meant that the schools we listed opted to move closer to the new neighborhoods formed by families who had left the city center, and who had traditionally used these schools. This prompted changes in the connotation and the role of the school building in relation to the city. Liceo $\mathrm{N}^{\circ} 7$ in Providencia and Liceo $\mathrm{N}^{\circ} 1$ for Girls in Viña del Mar relinquish the image of civic or state building and adopt that of a service building. The typology of the new model offers classrooms and courtyards that are neutral, with no undertones, and eliminates the residential blocks and workshops. The new model was developed in Santiago and throughout Chile during the 1960s by the Sociedad Constructora de Establecimientos Educacionales.

The private schools in Santiago, most of them formed by or associated with religious congregations, set up new establishments on the east side of the city, and their relationship with their environment was no longer dictated by a 
de edificio cívico republicano para pasar a ser un edificio de servicios, cuyo motivo es hacer visible una tipología de aulas y patios sin carácter representativo alguno; simultáneamente, y quizás por extemporáneos, son excluidos el internado y los talleres. Esta nueva modalidad fue desarrollada en Santiago y también a lo largo del país por la Sociedad Constructora de Establecimientos Educacionales en la década del ' 60 .

Los colegios particulares (en el caso de la ciudad de Santiago) que en su mayoría correspondían o se asociaban a colegios de congregación, formaron nuevos establecimientos en el sector oriente de la ciudad, ya no bajo la presidencia de la iglesia como fachada de relación con el entorno, sino que emplazados en amplios terrenos de varias hectáreas. Lo ocuparon a la manera de un campus, que podría corresponder a la imagen del campus universitario o bien a la estructura que tenían con anterioridad los colegios de colonia anglosajones (como el Grange School, el colegio Mc Kay, o el Nido de Águilas). En estos nuevos colegios el campo deportivo pasó a ser parte protagonista de la formación en reemplazo del museo y el teatro. En casi todos estos casos los edificios que albergan la docencia y salas se ordenan en torno a canchas; por su carácter religioso conservarán la iglesia como entidad construida a través de la cual se relacionan con la comunidad, pero ésta ya no preside la relación o fachada exclusiva entre lo público y lo privado.

\section{Momento tercero. 1980 - 2000:}

\section{Institucional o doméstico}

A partir de los años ' 80 se produce un auge en la construcción de colegios particulares en Santiago y provincias de Chile, motivado, entre otros, por el desarrollo económico del país, que permitió un mayor acceso de la población a la educación privada. Los nuevos colegios particulares ya no son mayoritariamente colegios de congregación, aunque muchos de ellos son confesionales, fundados y dirigidos por laicos.

A partir del año 1997 el Estado da también un nuevo impulso a la educación al proponer la "Jornada única escolar", medida que provoca un déficit de aulas en todos los colegios que hasta ese entonces funcionaban en 2 jornadas.

Retomando la relación colegio-fachada-ciudad, reparamos, en el caso de los nuevos colegios particulares, que éstos se emplazan en los límites del crecimiento de la ciudad, siendo así anticipadores de la expansión urbana aun no existiendo un barrio establecido. El colegio es un agente de consolidación, pues se hace denominador común que los padres elijan vivir cerca del colegio de los hijos para evitar traslados. Esta identificación entre barrio y colegio en unidad hace que éstos se construyan hacia su exterior como una casa agrandada, la "mansión del barrio" que reúne en un nuevo rol de educadores, a los padres con los hijos. No es raro que en estos colegios los papás vayan a hacer deportes con sus hijos los fines de semana, o lo utilicen como lugar de fiestas familiares. El edificio escolar ha perdido su condición de ser constructor del espacio que preside la ciudad volviéndose un asunto doméstico.

En el caso de las nuevas escuelas (municipales, particulares subvencionadas y particulares para personas de recursos medios y bajos) que se construyen producto de la extensión de la jornada, podemos agruparlas en torno a dos vertientes. La primera, aquellas que siguen el modelo doméstico de los colegios particulares construidos en los años '80, pero sólo en su forma externa, pues carecen de una infraestructura interna equivalente. En el segundo grupo se retoma la idea del edificio de servicios de los años " 60 , pero construyendo una "imagen institucional" o corporativa cercana a una lógica empresarial. Producto de ello, y church-like facade. Instead they set themselves up in broad open spaces, and organized themselves along the lines of a university campus or similar to the structure of the Englishspeaking community schools (The Grange School, McKay School or the Nido de Aguilas). Sports grounds took a leading role, replacing the previous museums and theatres; in almost all these cases, the teaching buildings are organized around the playing fields. The schools' religious origins meant they kept the church presence in a chapel building, through which they related to the community, but it ceases to be their facade, the dominant factor in the relationship between public and private.

Third moment. From 1980 to 2000: institutional or domestic

From the 1980s onwards there is a building boom in private schools, in Santiago and the provinces, driven partly by economic growth as more people have access to private education. The new schools are no longer mainly attached to religious congregations, but many retain a religious character, although founded and directed by lay people.
From 1997 onwards the state also gives education a new push with its plans for a full school day. Until then, the state schools worked a double shift, so the new measures meant classroom shortages in all these schools.

If we look once more at the relationship between school, facade and city, we note that the new private schools are established on the outskirts of the growing city, anticipating urban expansion even where no settled neighborhood yet exists. The school acts as a consolidating factor, since parents commonly opt to live close to their children's school to avoid them having to travel. The identification between neighborhood and school as a unit means the latter presents itself externally as an extended house, the "neighborhood mansion" which brings parents together with their children in a new role as educators. Parents commonly take part in sports there at the weekends with their children, or use the buildings for family parties. The school building has lost its role in constructing the space of the city and become instead a domestic affair.

The new municipal, state-subsidized and private schools for medium and low income groups being built as a result of the full school day plan fall into two main categories. One group follows the domestic model of the private schools of the 1980 s, but in their external elements only, for they lack the equivalent internal infrastructure. The second group takes up again the idea of the services building of the 1960s, but with an institutional or corporate image closer to that of a business. As a result, and because of the gap between commercial and educational environments, their facades often take forms out of other contexts.

In both cases, of course, there are exceptions that offer new ways of thinking of school buildings. Whether they start from the premises of a new pedagogy or of an ethic for school life, they propose a new urban facade that distances itself from the city and turns inwards.

\section{Fourth moment: Dilemma}

Could a school be like the roof garden of the Le Corbusier's housing unit in Marseilles, where living in the architecture is an education in itself, a building as game, as experiment, as a real educational medium? What might set a limit between architecture and education? One 
1 Colegio Verbo Divino. Arq.

Pérez de Arce. 1950-1960

Arq. Piwonka. 1962

3 Colegio Santa Rosa de Lo

Barnechea. Arq. Cruz

Browne. 2000

4 Colegio Saint George. Arq.

Gustavo Munizaga. 1969-1971
1 Colegio Verbo Divino. Arq.

2 Colegio San Ignacio ? Pocuro. Arq. Piwonka. 1962

3 Colegio Santa Rosa de Lo Barnechea. Arq. Cruz, Browne. 2000

4 Colegio Saint George. Arq. Gustavo Munizaga. 1969-1971 por la distancia entre el ámbito comercial y el educacional, recurren en sus exteriores a formas que son sacadas de otros contextos.

Por cierto, en ambos casos se han construido excepciones que sí plantean una manera para repensar el edificio educacional, ya sea a partir de las nuevas prácticas pedagógicas o de una ética de la vida escolar, proponiendo un nuevo orden de fachada urbana que toma distancia respecto a la ciudad y se vuelca al interior.

\section{Momento cuarto: Dilema}

¿Podría ser un colegio lo que es el techo jardín de la Unidad Habitacional de Marsella de Le Corbusier? ¿una arquitectura cuyo habitarse sea ya un acto educacional? ¿un edificio cuya especificidad construida es un juego, experiencia o medio educador eficaz?

¿Cuál podría ser el límite entre arquitectura y educación?

Un límite posible aparece al no hacer de la arquitectura un instrumento objetivo de comunicación.

La arquitectura, en este caso, debiera abrir el sentido de la palabra "educar", que viene de ducere, "sacar fuera"; e introducir a alumnos y profesores en un espacio en que las relaciones habituales en que se imparte la enseñanza provoquen la admiración; lugar donde se funda el aprender.

Por ejemplo, en los colegios y escuelas actuales hay algo que se acepta como dado y que no se ha revisado del todo, quizás por pedestre. Es la identificación entre sala de clases y curso al que se pertenece. La sala es -en general- el único lugar donde se imparten todas las asignaturas salvo las no regulares o aquellas cuya especificidad las hace más dificultosas. ¿No podría pensarse, en vez de salas y corredores, en un colegio que se ordenara $-\sin$ destruir la necesaria pertenencia a un curso- ya no desde la sala sino desde las materias, las que por ejemplo sí tienen un lugar fijo a la manera de la sala de música o los laboratorios a los cuales se va? Este modo de transitoriedad de los alumnos al interior de los colegios, sin relación con un lugar único como lo es la sala, pero sí con relación a múltiples y determinados lugares, aquellos de las asignaturas, ¿acaso no provocaría en estos traslados un nuevo modo de pensar y hacer el espacio arquitectónico, de repensar la permanencia, los recreos, la disciplina y las relaciones con el mundo que se dan al exterior de los colegios? En ese caso, ya no se trataría sólo del modo en que se construye la fachada urbana si no en cómo se construye la fachada interna, o aquella fachada necesaria del estudio. ARQ possible limit emerges when architecture is not used an objective tool of communication. In this case it must operate in the sense of the word "educate" which comes from ducere, to bring out, and must bring together students and teachers in a space where normal teaching relations prompt admiration, the place where learning is founded.

In today's schools, for example, there is a given factor that has never been examined, perhaps because it seems trivial or pedestrian. This is the identification between the classroom and the class group it belongs to. All teaching normally takes place in the classroom except for non-curricular activities or specific subject areas where this is more difficult. Perhaps, without losing the necessary sense of class group identity, a school could be structured not around classrooms and corridors but around subject matter, like the subjects that do have a fixed room -the music room or the laboratories, that students must move to. Might not this transitory mode for students within the school, not fixed in a single classroom but relating to various set teaching centers, produce new ways of re-thinking and re-working architectural space, of

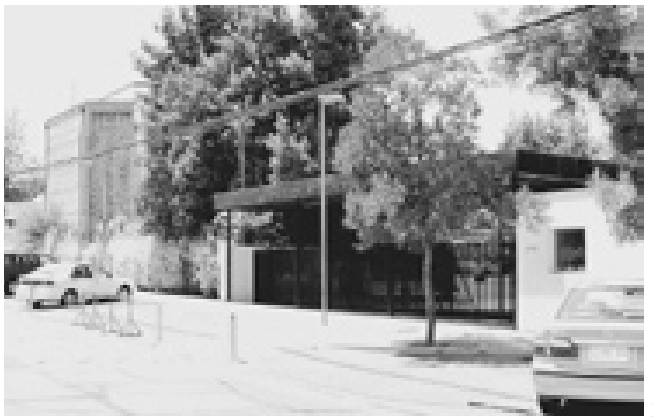

re-thinking permanence, playtime, discipline, and relations with the world outside the school? Then it would not only be a matter of how to construct the urban facade but how to build the internal facade, the facade for study. ARQ
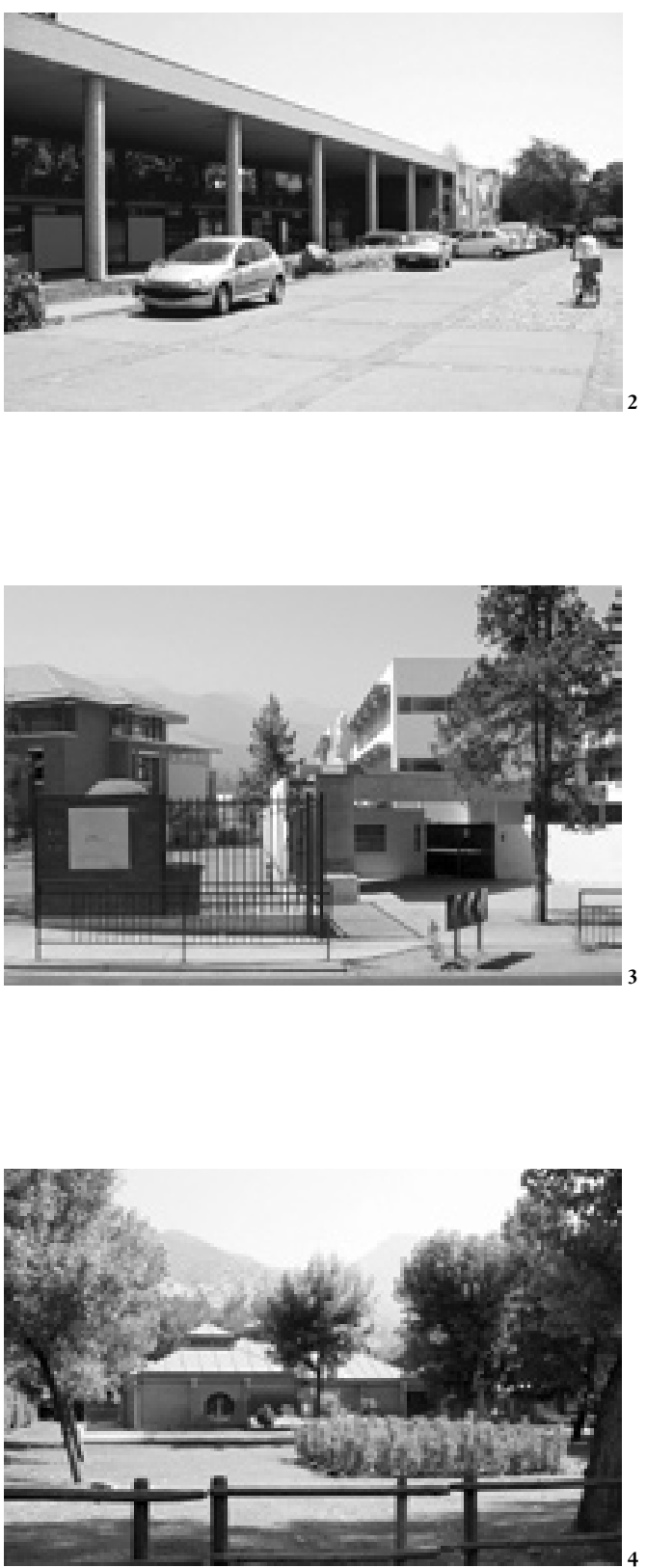


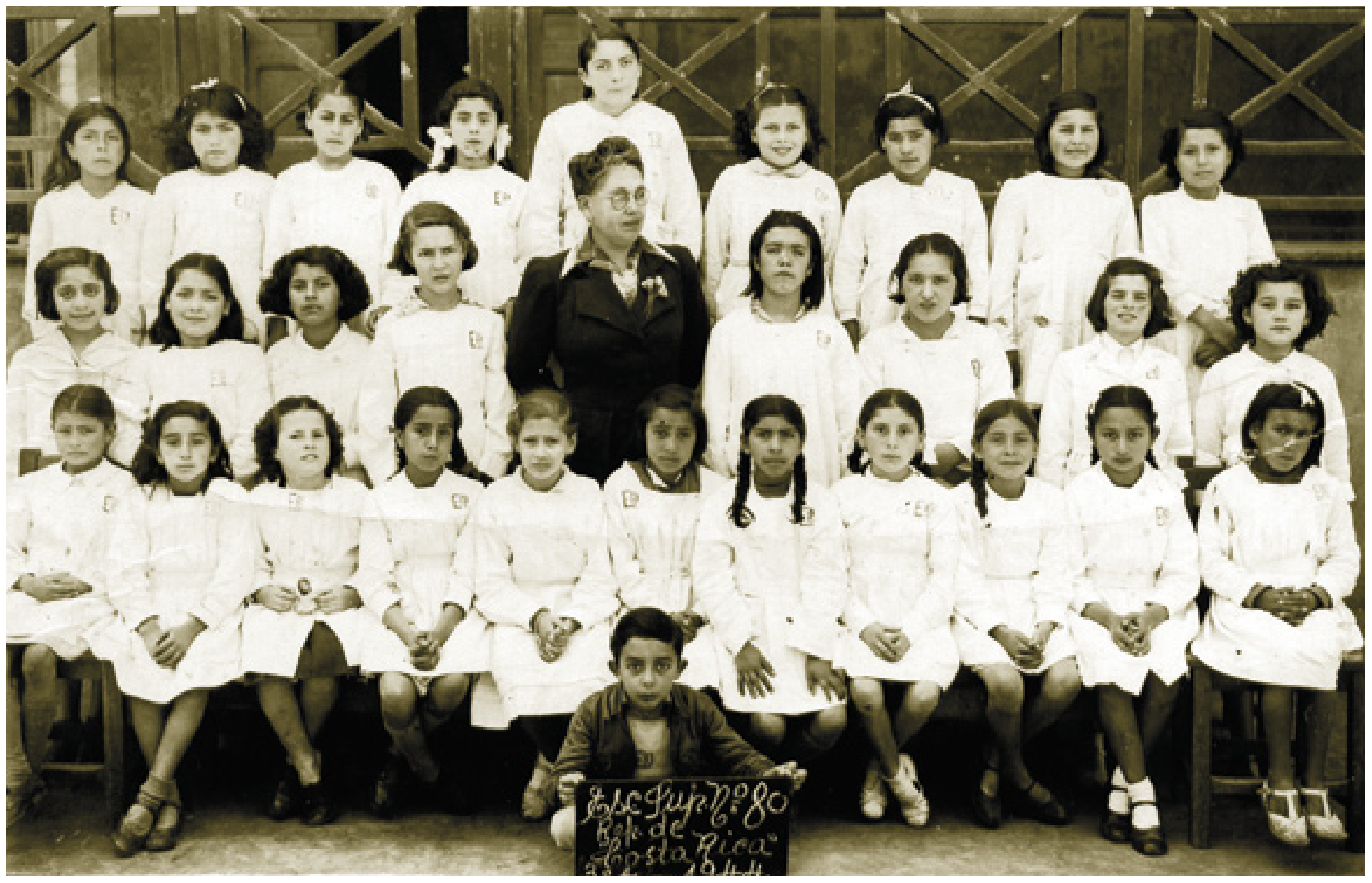

Escuela Superior N ${ }^{\circ} 80$ "República de Costa Rica”, $3^{\circ}$ año de preparatoria. Santiago, Chile, 1944. School No 80 "República de Costa Rica”, 3"th grade. Santiago, Chile, 1944 


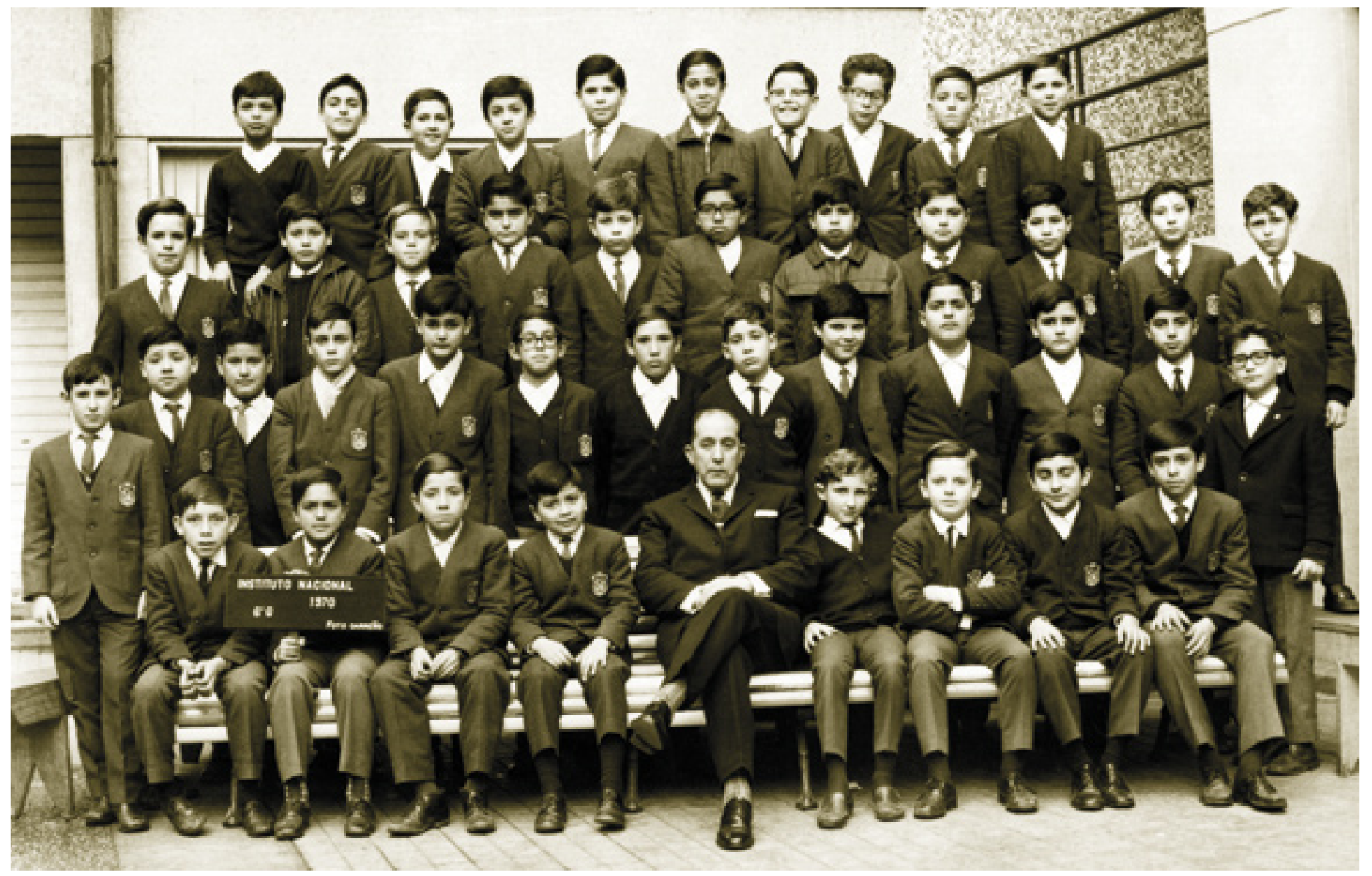

